RESEARCH ARTICLE

\title{
Peace Education: A Case Study of a Montessori School in Lebanon
}

Mazen Kotob, Venise Antippa,

Lebanese International University, Lebanon

\begin{abstract}
Lebanon suffered a civil war that torn its society. The third generation is still living the instability and conflicts that their grandparents experienced when the war started forty-five years ago. Nowadays, there is a need of a substantial change and children have the power of creating peace and making a major transformation of the society. Therefore, educators should believe in children's power. The inclusion of a practical Peace Education Program in the Lebanese National Curriculum is, from the perspective of the researches, the tool children need to lead the future transformation. Peace Education can help them to know themselves and understand that everyone is an important part of the community and the country. Accordingly, this study examines the Peace Education Program at the first Montessori School in Lebanon and the teachers' level of awareness of implementing it through their teaching practices. The level of awareness is related to the four pillars to be developed in the students according to the Montessori approach to Peace Education: Self-awareness, community-awareness, cultural-awareness, and environmental-awareness. The results of the study show that the director and the teachers have the adequate knowledge and awareness about this approach and they implement it, complying with Montessori's principles and concepts.
\end{abstract}

Keywords: Montessori, peace building, peace education, peace flower model, Lebanese curriculum

\section{Introduction}

Learning objectives are planned according to the three major learning domains recognized by Bloom: cognitive, affective and psychomotor (Oliva, 2004). Most of education programs focus on cognitive and psychomotor learning domains, leaving the affective one aside. Unfortunately, educational systems and consequently schools, underestimates the importance of the affective development in children.

Lessons in a formal classroom are planned or designed for cognitive outcomes, while teachers usually disregard the affective domain without realizing that this domain may enhance the student's learning. Educators have the responsibility to help the children's development in the three domains. Education involves more than preparing the learners for work. It goes beyond that as there is a need to prepare them to be good humans. The affective domain is essential to help children in their development in all aspects. 
Learning in the affective domain means children learn about their feelings, respect for others, appreciation, attitudes, interaction with others, and self-understanding. It fosters the development of values and peace. In other words, it changes the student's behavior positively. Children have to be helped to know themselves, connect to the community, and understand that they are part of the world around them and that everything is interconnected. Peace Education encourages young people to acquire knowledge and values, enhances skills, and develops attitudes and behaviors that are needed to live in harmony with oneself, others, and the natural environment around them. Peace Education promotes conflict resolution that leads to peace. Peace Education is important to be incorporated in programs for children because they are still building their identities and values. Peace Education as defined by Lioral M. "is a pedagogical proposal that can contribute to improve not only the teaching-learning process, but also the world" (as cited in Isoraite, 2019, p. 44).

Peace Education is taught in schools in some countries and this practice is attributed to Maria Montessori and John Dewey. Montessori (1951) believed that "Establishing peace is the work of education" (p. 476); therefore, she put efforts to foster peace in her schools on three levels: The individual, community, and the globe. The individual level relates to self-awareness (body, mind, emotions, and spirits), while the community awareness refers to the relations with others, and the global level refers to cultural and environmental awareness Montessori (1951).

The social, economic, and environmental problems that we have in Lebanon are all rooted in the conflicts between the different religious sects and different political parties that coexist in Lebanon. After 15 years of civil war (1975-1990), the government put a plan for the country to recover from the wounds of the war, but that plan has failed.

Peace could contribute to the development of the nation. Thus, if there is no peace, the country will not develop and the social, economic, and environmental problems will not be solved. Moreover, every individual in the society will be affected if Lebanese people do not live in peace with each other.

In the aftermath of the civil war, the government developed a new curriculum, hoping that the new generation will help in rebuilding the nation. After twenty-three years of implementation, the same problems are still deeply present in the country. In consequence, there is a need for a big change in the individuals that lead the society. This must start in schools by building a new educational program that includes Peace Education as a tool for transformation. Peace Education can help young people to know themselves and understand that everyone is an important part of the community and the country as a whole. We have to invest in the youth because they are the future.

This research aims to examine the Peace Education program in the first Montessori school in Lebanon and the teachers' level of awareness of implementing the Montessori philosophy of Peace Education through their teaching practices in the classroom. Both a qualitative and quantitative methods are used to identify the practices that promote Peace Education in the Montessori school. This data will be contextualized within recent studies on Peace Education and statistical analysis of the practices in the school. 
Several studies across the world have highlighted the effects and importance of Peace Education in schools, especially in the countries that have undergone war. According to Castro (2008) "Peace education, or an education that promotes a culture of peace, is essentially transformative. It cultivates the knowledge base, skills, attitudes and values that seek to transform people's mindsets, attitudes and behaviors that in the first place, have either created or exacerbated violent conflicts" (p. 27).

However, very few studies have been carried out about Peace Education and its relevance to build the Lebanese society on the principles of the importance of peace among all the citizens of this country. After a long civil war in Lebanon, in 1997 the Lebanese government published a developed curriculum, hoping that the new generation will help in rebuilding the nation. This curriculum, which is still in place nowadays, includes a Civics textbook that covers different topics, such as peace, human rights, and conflict and dialogue. A research has been conducted by Maha Shuayb (2015) about Human Rights and Peace Education in the Lebanese textbooks and it has concluded that Peace Education is presented only in one unit in Grades 8 and 10 and focuses only on conflict resolution and dialogue. Moreover, the lesson objectives in the Civics textbook focus mainly on the theoretical knowledge while the development of skills is totally missing. The pedagogy followed in the textbook is descriptive, lacks critical thinking, and the steps for its implementation is missing. Thus, the textbook is theoretical and is oriented to provide a level of knowledge of the concepts; however, those concepts are not further translated into abilities or skills for practical implementation. Without a solid practical guidance, the acquired knowledge is likely to be lost once students leave schools and indulge themselves in daily activities. Most importantly, the textbooks lack activities that could promote peace building.

Another study was conducted by Khayrazad Jabbour (2013) in which the author highlights that Peace Education needs to be incorporated in the Lebanese curriculum to promote peace and cultural awareness in order to establish a healthy relationship amongst the different communities of different cultural backgrounds in Lebanon.

Ghada Chehimi (2012) has also conducted a research to assess university students' attitudes toward peace and Peace Education in the Lebanese school system. This research has found that participants in the study believe that peace education can be implemented in Lebanese schools "if the following conditions are met: (1) the term peace is familiar, (2) there is a belief that peace can be taught in schools, (3) giving support if schools teach peace, (4) people should not tie peace to politics, and (5) formal government strategy should be designed to counter the notion that Lebanon cannot teach peace in schools" (p. 794).

In view that the researches carried out on Lebanon shows the need to improve what has been done in terms of Peace Education at schools since the 1997 curriculum. This study intents to identify what are the elements or factors that require enhancement within that curriculum. In that connection, this study will take the Maria Montessori approach to Peace Education as a reference of the standards to be reached and will then look at the Lebanese schools approach based on the current curriculum. 
Maria Montessori was one of the first pioneers in incorporating Peace Education in schools after her experiences of the two world wars. According to Montessori (1949) "Establishing lasting peace, is the work of education" (p. 24). From her perspective, children are the hope of tomorrow and the educators' role is to prepare them for the future through education "because education is capable of saving humanity" (Montessori, 1949, p. 30).

Peace Education is a major component of the Montessori classroom. Sonnie McFarland (2012), a Montessori teacher, developed a model for Peace Education called the "Flower of Peace" using the principle of lotus flower model of peace. It is a holistic model that works as the framework for peace education. The model is composed of four petals where each petal represents one of the four kinds of awareness that are embedded in the Montessori approach to education: Self-awareness, communityawareness, cultural awareness, and environmental awareness.

The first Montessori school in Lebanon opened in September 2019, so there are no researches that have been carried out in this country concerning Peace Education in a Montessori classroom. This study will focus on how Peace Education is being addressed in the first Montessori school in Lebanon.

The purpose of this research is to examine the Peace Education program in the first Montessori school in Lebanon. Data are collected through measuring the level of the teachers' awareness of practices and implementation of the Montessori Philosophy of Peace Education in the classroom. The level of awareness is related to the four aspects that should be developed in the students according to the Montessori approach of Peace Education: Self-awareness, community-awareness, cultural awareness, and environmental awareness.

\subsection{Research Questions}

In this study the researchers search for the answers to the following questions:

1- Does the Montessori school promote Peace Education through the four aspects: self-awareness, community-awareness, cultural awareness, and environmental awareness?

2-To what extent are the teachers in the Montessori school aware of the four levels of awareness: selfawareness, community-awareness, cultural awareness, and environmental awareness?

3-What lessons can we learn from the Montessori approach of Peace Education to be incorporated in the Lebanese Curriculum?

\section{Literature Review}

\subsection{Definitions of Peace Education}

According to Ian Harris and Marry Lee Morrison (2013) Peace Education is a "process that involves empowering people with the skills, attitudes, and knowledge to create a safer world and build a sustainable environment" (p. 10). While, UNESCO defined Peace Education as a way "to establish and nurture respect, and skills needed to build a culture of peace" (UNESCO, 2008, p. 3). 


\subsection{Opinions on Peace Education}

Ian Harris (2013) believes that Peace Education can be used to "inoculate students against the evil effects of violence and to teach them the skills to manage their conflicts in a nonviolent way and by motivating them to choose peace when they encounter conflict" (p. 12).

UNESCO's activities and projects in Peace Education include two fundamental concepts which are respect and skills. "Respect refers to the development of respect for self and for others; skills refer to specific communication, cooperation and behavioral skills used in conflict situation" (UNESCO, 2008, p.3).

Pope Paul VI was convinced that peace can be built up by everyone, so in 1967 he launched the "World Day of Peace". He also believes that to reach peace, we have to teach it especially to young people. Pope John Paul II, celebrating the World Day of Peace in January 1979, added that "Parents and educators help children to experience peace...young people are the builders of peace. Together, they can produce this great common construction which is Peace”. (Pope John Paul II, 1979, p. 1).

John Dewey, a pioneer in peace education, was convinced that schools can be the starting point for dynamic change and the reform of society in the name of peace. However, he also emphasized that each student has to believe that he/she has the potential for building a nonviolent world (Howlette, 2008).

According to Betty Reardon, a peace educator and activist, peace education theory is built on the belief that education and society are intertwined. She believes that peace education is a tool "to transform the present human condition by changing the social structures and the patterns of thought that have created it." (Reardon, 1988, p. x). Thus, peace education is the strategy that educators can use to change and build new values in children (Snauwaert, 2012).

\subsection{Importance of Peace Education in Schools}

In this world, we are in an urgent need for Peace Education. Different forms of violence have increased such as genocide, domestic violence, sexual abuse, racism, bullying, etc. Schools and teachers are those who can help through Peace Education to make a change (Sheykhjan, 2014).

According to the Spanish educator Cabedo-Mas (2015), "the school plays an important role in the construction of communities by raising awareness to focus permanently on enhancing peaceful relationships between people and with the nature" (p. 78). Moreover, the role of the schools is to rebuild societies, especially in the context of post-war though Peace Education. Galtung, the father of Peace Studies, argued that peace can be achieved through education.

\subsection{Early Childhood as a Foundation for Peace}

Educators and child experts indicate that the early years from birth to age 8 are fundamentally important. Those years are the foundation in the life of the child in which he/she develops linguistic, cognitive, social, and emotional skills that are needed in life (Bakken, et al., 2017). 
There is a universal accord among educators with regards to the benefits of starting teaching kids about peace from early years due to its positive outcomes in the future. According to a research carried out in Pakistan, the teachers stressed on the importance of including peace-building elements in the Early Childhood Education (ECE). In their opinion, there is an urgent need to introduce peace-building concepts in the early years of the child development because it can bring about a change in making peace in the world (Lasi, Jiwan, Batool, Dhanani, \& Shrestha, 2017).

UNICEF stresses the importance of including peace building in early childhood education. The first years of development is one of the most sensitive periods in the individual's life because during this period relevant changes happen in the structure of the brain. The early years are the foundation for developing skills such as empathy, tolerance, cooperation, regulation of impulsive behavior, and peaceful negotiation of conflicts. Thus, the benefits are many if we start building peace in this first life stage of the child's life (UNICEF, 2014).

\subsection{Overview of Maria Montessori's Philosophy}

Maria Montessori was an Italian physician and educator. She was the first woman in Italy to graduate as a Medical Doctor. Through her work with young children at Casa dei Bambini, she founded the principles of the Montessori Method of Education. Montessori philosophy in education is a holistic approach which emphasizes the physical, mental, social and spiritual development of the child (Lillard, 2005).

Montessori lived through two world wars, and this experience was reflected on her philosophy in education. She considered education as the best way to achieve peace. She believed in building a better society with no violence and this objective, in her opinion, can be achieved through children because they are the builders of civilization and humankind. Montessori concentrated efforts to bring about peace through education and held several peace conferences in different countries, which later were published under the title "Education and Peace". Montessori was nominated three times for the Nobel Peace Prize and in1936 at the European Congress for Peace in Brussels, she highlighted that the need of implementing peace is education (as cited in Baligadoo, 2014, p.429).

Maria Montessori (1949) urged the importance of the cohesion of society and emphasized the significance of early years in childhood. In the early years of development the formation of the character starts and develops in the right environment of freedom and order. She believed that to construct this cohesion we must begin with the child's personality or inner self which is formed through experiences in the right environment. For example: The child in a Montessori classroom has the freedom to choose the activity and work without any interruption from anyone. The continued concentration on activities of their own choice allows children to enhance their inner calmness which, in turn, leads to inner peace. Moreover, the Montessori classroom is a mixed-age environment which symbolizes a mini society the same way as in the family, workplace, and in a community where there are constant interaction, problem solving, peer to peer teaching, collaboration and socialization among the children. 
Montessori (1967) did not believe in rewards. In her opinion, rewards generate envy and rivalries which lead to conflict and this does not help in building kids' personality nor the cohesion in society. On the other hand, the traditional schools create a culture of competition among children instead of building the spirit of helping peers and collaboration to achieve goals. This does not help in educating children for peace.

In the Montessori classroom, there is no grading which is a kind of reward. In Elementary schools, much of the Montessori work is done in collaboration with other kids; therefore, they receive feedback from their peers and point out errors in each other's work. In the absence of grades which creates a competitive atmosphere, the environment in the Montessori classroom is supportive and collegial, but not competitive as in the traditional classroom (Lillard, 2005).

Montessori classroom helps the kids in developing self-awareness. Children have the freedom in the classroom to develop naturally which helps the kids to learn about themselves. Children also learn indirectly to have control over their actions through the type of work that attracts them. The free choice concerning the activity the children choose, the peer they would like to work with, the place to perform the task, and the time they need to achieve it. This help the kids to make decisions, be responsible, and improves their emotional well-being (Lillard, 2005). The freedom that is given to the children to choose the activity they are interested in helps them to concentrate and over a concentration period, they do not get interrupted. This deep concentration leads to what Maria Montessori calls normalization (Lillard, 2005). A normalized child has love for work, could concentrate on what he or she is doing, has selfdiscipline, and is a social person. (Somerton-Burkhardt, 2015). Although Montessori believed that freedom help children to make more constructive choices, but this freedom has limitations: It is limited to what works for the classroom and society. Freedom with limits teaches kids to respect oneself, others, and the environment around them. The materials also are designed for the kids to help them to develop self-awareness and various potentials. The kids have to compare and contrast, explain how and why things happened, evaluate their work, determine what is wrong and what is right, and form opinions which fosters critical thinking.

Dr. Montessori saw a need in children to become independent, and the role of the adults is to help them toward that independence. A Montessori teacher is a facilitator; she does not practice authorization that commands. Her responsibility is to prepare an appropriate environment where children can self-develop, observe like a scientist the development of the child without interruption, and interfere when it is necessary (Montessori, 1949). In case there is a conflict between kids, the educator allows the children to solve their own issues. Through grace and courtesy lessons, children develop their interpersonal skills, appreciation of others' order of the space, and their responsibilities to their environment. (Schaefer, 2015). Through grace and courtesy, students become more self-regulated and independent, and it can positively enhance the learning environment (Mahan, 2018).

Montessori (1949) emphasized helping kids to connect to nature: "The child has to be in contact with nature and have a direct experience of it." p67. She believed that every child has an innate love for 
nature; children are interested in nature and living things, they are spontaneous observers of nature (Montessori, 1949).

\subsection{Montessori Peace Education Framework: Content of "Peace Flower" Model}

Peace Flower model was created by Sonny McFarland based on Maria Montessori's philosophy of education. The Peace Flower model has four categories: 1) self-awareness, 2) community awareness, 3) cultural awareness, and 4) environmental awareness.

McFarland (2012) believes that people become more respectful and peaceful when they have high consciousness and awareness of themselves, others, cultures and the environment. The four elements of the model can be seen as the petals of a flower that are interrelated and the core of each element is the consciousness or the awareness of its nature or spirit. All of the four aspects of the "Peace Flower" model are embedded in Maria Montessori's approach of education and her philosophy of peace education.

\subsubsection{Self-Awareness}

Psychologists Shelley Duval and Robert Wicklund developed the theory of self-awareness. The theory proposed that directing our conscious attention is the essence of self-evaluation. We become selfconscious and self-aware when we are able to compare and evaluate our current behavior to standards and values (Silvia \& Duval, 2001).

Self-awareness is a self-examining process to understand one's values, thoughts, and feelings. Daniel Goleman (1995) defines self-awareness as "knowing one's emotions, personality traits, and own boundaries" (p. 52). He stresses on knowing our feelings and have control over them because selfawareness can influence both our work and social life. Thus, for Goleman self-awareness means the ability to monitor our thoughts and emotions and the effect they have on others. Knowing yourself better helps to reach an inner peace and that reflects on the relations with others in the community.

A research carried by Heidi Flavain (2016) about self-awareness development found that educators need to help children to develop their self-awareness through different experiences. Since selfawareness relies on life experiences, teachers have to be careful in choosing the activities and the ways of interaction in the classroom to better contribute to the children's self-awareness development.

Another researcher, Alfonso (2014), also stresses on the important role of educators in helping children to develop and create a positive self-image built on love and respect of oneself. Through love and respect of oneself, love and respect for others can grow. Children get to know themselves and their feelings through interactions with adults, peers, and the environment. The teacher has to give children the opportunity to experience things by themselves, to make choices, and appreciate their efforts. We can conclude that social interactions, the environment, and teachers have a big impact on building children's self-awareness. 


\subsubsection{Community Awareness}

Community awareness is one of the aspects of the affective domain and nowadays is one of the most needed aspects. It is the ability to recognize others' inner state, feelings and thoughts, and have empathy to other people who are from different backgrounds and cultures (Huynh, 2018). Bruce (2019) points out that one essential part of community awareness is the ability to understand others' emotions within their different circumstances, which generates sympathy and empathy toward them (as cited in Huynh, 2018, p. 7). In a study carried in Vietnam, Huynh found out that the correlation between community awareness and responsible decision-making is high in primary school students. Thus, he concluded that the better people understand others, the more responsible decisions they make. Students in a classroom community needs to understand that the group is important for them and they are important for the group (McClellan \& Kinesy, 1999). When children are aware that they are part of a whole and realize that their decisions can affect others, this makes them reflect on the advantages and disadvantages of their decisions and drive them to choose the appropriate ones.

The philosopher Noddings, the founder of Care Theory, urges the importance of care and its impact on peace. She insists that it is the educators' responsibility to establish in children caring relationships. Also, she believes that to reach peace first we have to care and understand oneself then with the help of adults (carers, parents, and educators) this care can grow and expand to care for others (Baja, 2008). Her beliefs about the role of education align or meet with Maria Montessori's philosophy of education on the importance of developing caring relationships among children.

Alfonso (2014) indicates that it is the responsibility of the educators to create in children an appreciation and positive understanding of diversity. The researcher believes that in order to build good relations with others and to value their backgrounds and culture, first people have to know themselves and value their own culture. She argues that in the same way educators must help children to develop self-awareness and they must aim to help kids to know their background and culture.

McClellan and Kinsey (1999) conducted a study about children's social behavior and its relation to mixed-age and same-age classrooms. The kindergarten teachers rated children's behavior in mixedage classes as more pro-social, less aggressive, and friendlier. The findings showed that there is a positive effect on children's pro-social behavior in the context of a mixed-age classrooms. Moreover, children in mixed-age classrooms appeared to experience less social isolation compared to children in same-age classrooms. Also, aggressiveness was less noted in mixed-age than in same-age classrooms. The same research was carried out on third-grade students and the teachers noted that the children who were in mixed-age classrooms and later on attended same-age classrooms continued to be significantly less aggressive and more pro-social. Montessori was one of the pioneers in creating mixed-age groups because this generates an atmosphere of constant interaction with the support of the teacher, and they can understand the interconnectedness of human to human relationship.

Moreover, mixed-age classrooms create a space for collaboration and, precisely, collaboration is

one of the $21^{\text {st }}$-century skills. It does not only affect the student learning and cognitive development, but it has a huge impact on the community skills of an individual. Collaboration is a skill that is needed for 
society and workplace. It teaches students to share authority, respect others' opinion and perspective, converse with peers, be responsible of their actions, and work with others to achieve group goals and improve the effectiveness of the group (Kermanshahi et al., 2012).

\subsubsection{Cultural Awareness}

As defined by Guiso, Sapienza \& Zingales (2006) culture is "those customary beliefs and values that ethnic, religious, and social groups transmit fairly unchanged from generation to generation" (p. 23). On the other hand, Campinha-Bacote views cultural awareness as the "self-examination and in-depth exploration of one's own cultural and professional background" (as cited in Carter \& Wheeler, 2019, p.224). In order to develop a cross cultural perspective in the world, it is important to understand that nowadays most societies in the world are multicultural. Also, in the era we are currently in, people and organizations communicate, coordinate, and collaborate across geographic and cultural boundaries (Livonen, Sonnenwald, Parma, \& Poole-Kober, 1998).

A report by UNECSCO (2013) about the role of culture in peace highlights culture as an essential factor for both sustainable development and lasting peace. UNESCO recommends including culture in educational programs for children because it may play an important role in building confidence and tolerance among multicultural communities. Also, promoting cultural activities and creativity in the areas that have been affected by conflicts can help communities to reconnect with their identities which is the beginning to heal from the scars of war. Moreover, cultural activities can help to foster appreciation of cultural diversity and mutual understanding among each other. Knuston (2006) highlights the importance of developing cultural awareness in students which, Knuston argues, starts by making them recognize their own culture in relation to other cultures (Knutson, 2006, as cited in Shemshadsara, 2012).

There are different ways to raise students' cultural awareness. Jin-Feng (2007) pointed out that teachers can help students to improve their sensitivity to culture and absorb new cultures by using various teaching methods. Thus, according to the researcher, it is not enough to introduce children to knowledge to help them acquire the needed skills, educators have to guide children to analyze, discuss, compare, and contrast cultural ideas and concepts. Moreover, the researcher advices the language teachers to promote cultural awareness through role playing, dramas, maps, photographs, songs, celebrating foreign festivals, costume parties, exploring foreign food, and using audio-visual media.

\subsubsection{Environmental Awareness:}

Environmental awareness is the concept of being aware of the state of the environment. According to Dimante et al. (2016) raising awareness in children about environmental issues has a significance impact on reducing pollution.

The earlier kids learn about the environment, the more they will care and protect it. The development of environmental awareness can help to improve the humans' relation with the nature, increase our respect for it, and promote our appreciation and responsibilities toward taking care of the environment (Skoumios et al., 2013). 
A study carried out by a group of researchers concluded that schools have a strong effect on children's environmental attitudes and awareness, especially the schools which teach science in handson approach (Van Petegem et al., 2010).

The United Nations Environment Agency recognizes education as the primary agent for social change towards sustainable development. It also realizes that environmental education is a continuous and lifelong process; therefore, educators have to use different and innovative teaching approaches to teach environmental issues (UN Environmnet, 2020).

It is necessary to help children to be aware of their relationship with nature and give them the opportunities through experiences to understand the interconnection and the interdependence between humans and the natural environment around them (Alfonso, 2014). Educators have the power to build bridges between children and their natural environment.

A research carried by Russell (2014) showed that children become more connected to nature when they are given the opportunities to be regularly in contact with nature such outdoor activities as playing. Exposing children to nature from a young age can help them to understand the world and their place in it. This can provide the chance for environmental peace-making (Alfonso, 2014).

On the other hand, Chaturvedi (2014) stated that through education we can enhance environmental awareness. According to this researcher, teaching environmental concepts should be through the three domains of Bloom's Taxonomy: the cognitive, the affective, and the psychomotor. Having knowledge and loving nature are important in environmental education; however, the psychomotor domain should be included in learning through activities such as plantation, recycling, and cleaning.

Finally, Littledyke (2008) argues that the cognitive and affective domains should be integrated in environmental education. In his opinion, educating children about environment using the cognitive domain is not enough due to the fact that teachers have to use effective teaching to foster a sense of interest, excitement in learning, respect, and reverence to the environment, and to make students understand our interconnection with the universe.

\section{Methodology}

The methodology is oriented to obtain answers to the following research questions: (1) Does the Montessori school promote Peace Education through the four aspects: self-awareness, communityawareness, cultural awareness, and environmental awareness? (2) To what extent do the teachers in the Montessori school are aware of the four levels of awareness: self-awareness, community-awareness, cultural awareness, and environmental awareness? (3) What lessons we can learn from the Montessori approach of Peace Education to be incorporated in the Lebanese Curriculum? This research utilizes a case-study design and contains a combination of qualitative and quantitative approaches. 


\subsection{Population of the Study}

The target population for this research are the principal and the teachers of the Lebanese Montessori School in Beirut. The Lebanese Montessori School has opened recently, in September 2019, and is the first Montessori school in Lebanon. It offers pre-school and elementary programs, using the Montessori education approach and philosophy. The principal, who is also the lead teacher, holds an AMI (Association Montessori International) certificate that is internationally recognized. The mission of the school is to provide an environment that promotes the children's holistic development in the intellectual, emotional, physical, and social aspects. The goal of the school is to prepare children to be responsible for one another's welfare, to care for all that surrounds, and to build a more peaceful world (Lebanese Montessori School, 2020).

\subsection{Procedure}

The aim of this research is to assess the implementation of Peace Education in the Lebanese Montessori School through analyzing the principal and teachers' level of awareness in their program and teaching practices at the classroom. The researchers have chosen a purposive sampling technique to collect the needed information from the Lebanese Montessori School.

\subsection{Data Analysis}

The researchers analyzed the result of the qualitative and quantitative collected data in order to measure the level of knowledge and awareness of the teachers' practices in the classroom with regards to the four aspects or pillars of the Montessori Peace Education Philosophy: Self-awareness, community-awareness, cultural-awareness, and environmental-awareness. These levels of awareness are supposed to be introduced to the students in the Montessori School.

\subsection{Instruments}

The researchers designed an interview as one of the data collection instrument for this study. The interview questions (see Appendix I) were aimed at eliciting relevant information concerning Peace Education in the Montessori school, the inclusion of Peace Education in the school's curricula, and the challenges to implement the Montessori philosophy in the context of the Lebanese culture and environment.

A questionnaire designed by the researchers (see Appendix II) was also utilized in the study. The content of the questionnaire was based on the information obtained from the literature reviewed. The questionnaire has four sections. Section "A" is about self-awareness and has 5 items. Section "B" focuses on community awareness", which has 6 items. Section "C" contains 6 questions on cultural awareness, and section "D" is made up of 5 items on the environmental awareness. The questionnaire was structured on a frequent 5-points Likert Scale, ranging from "never" to "always".

Responses to the questionnaire by the teachers were statistically analyzed with the data instruments of the study. The reliability analysis shows that the instrument is reliable with a reliability coefficient equal to 0.79 . 


\section{Findings}

\subsection{Principal's Interview}

The principal was interviewed to obtain relevant information concerning Peace Education in the Montessori school. The questions can be found in Appendix I.

The main goals of the Lebanese Montessori School are the development of the child in all aspects and the promotion of Peace Education. These goals are achieved through the integration of the five areas of learning into the Montessori classroom: 1) learning through practical life experiences, 2) learning through sensorial exercises, 3) learning through language, 4) learning through mathematics, and 5) learning through cultural approaches.

Furthermore, LMS also applies the eight Principles of Montessori education: 1) the absorbent mind, 2) learning in context, 3) intrinsic motivation, 4) connection between movement and cognition, 5) order in the environment and mind, 6) interest and flow, 7) learning from and with peers, and 8) free choice. Both, the Learning Areas and the Principles contribute to the buildup of the children's character and to the development of their self-awareness, community awareness, cultural awareness, and environmental awareness.

In classes oriented to early childhood, the teachers model grace and courtesy lessons. These lessons provide children with ways to behave and respect others. Additionally, through these lessons, teachers provide the children with examples of the words to be used in expressing their feelings and negotiating in order to solve a conflict. At later stages, teachers use role-play exercises with the children, aiming to practice what they have learned in terms of grace and courtesy skills as well as to foster the students' curiosity about the environment that surrounds them.

In older children classes, cosmic education is introduced to establish a global perspective. It develops the awareness of ecology of existence that gives every living thing a meaningful function in the universe. Children are taught about the universe, life on earth, human beings, and how language and numbers started. These lessons expose children at early age to global concepts which foster cultural, community, and environmental awareness. Through these lessons, children learn where the things they have and use today come from and explore how the contribution of people from around the world reach others. Moreover, these lessons help students to understand that they are a relevant part of a whole and that everything is interconnected. Thus, human beings are interconnected with everything in their environment and each thing has a task in this world. These lessons in her opinion "foster respect and appreciation for all living and non-living things in the environment."

Teachers in LMS use different approaches in developing peace through self-awareness, community awareness, cultural awareness, environmental awareness, and conflict resolution skills in all their students. They help children to have good communication and negotiation skills with their peers in case there is a misunderstanding or conflict among them to resolve conflicts peacefully. The teacher's role is to guide the children in recognizing and expressing their feelings and then to communicate with the peer that they have a conflict with. Sometimes the teacher asks the child who misbehaves to sit in a 
quiet place on a couch to reflect about his/her actions before having a conversation with the teacher. While teachers of younger children use a silent game which helps in finding inner peace. Moreover, kids take turns in keeping the environment clean, serving food, and setting the table which help in fostering community awareness and individual's contribution to the group. As a way of gaining knowledge about different cultures and respect for other communities in the world, LMS has assigned a corner in the lobby of the school for celebrating holidays and occasions to introduce the kids to other cultures through food festivals, costumes, and holidays.

The principal finds introducing the Montessori Philosophy to the Lebanese community challenging, but in her opinion, it is not impossible to integrate it with the current education system". In Lebanon, parents usually follow up their kids' progress in education through home works and grades. Since these two concepts do not exist in a Montessori education program, parents feel they do not have enough evidence of their children's education progress. Thus, Montessori methodology was found difficult to be accepted in the Lebanese society. "The change is slow", she says, "but it is not impossible because Lebanese people are open to new things and always want to improve themselves". Finally, the principal is convinced that "major changes in the world begin to influence children and that is why it is very important to introduce Peace Education at an early age". She strongly believes that "Montessori Philosophy in Education can bring peace to our community."

\subsection{Survey Responses by Teachers}

One hundred percent $(100 \%)$ of the teachers replied that they "always" encourage children to express their feelings and emotions, whereas, $75 \%$ of the teachers answered "often" for helping children to be proud of their work. As for giving time to children to self-correct their work, $75 \%$ answered "often"; and $75 \%$ of the teachers responded that they "always" create activities for children to take care of themselves. With regards to creating opportunities for the children to be independent, $75 \%$ responded that they are "always" so.

The responses on "self-awareness" reveal that in general the LMS teachers are highly aware of the importance of promoting self-awareness in the children and of the applications of this concept in their practices. However, the teachers have to consider giving more time to the children to self-correct their work.

One-hundred percent (100\%) of teachers answered that they "always" encourage children to build a harmonious relationship with their peers, whereas $75 \%$ of teachers replied "often" for: i) helping children to be aware of others' needs; ii) encouraging cooperative learning; iii) encourage children to value and respect other opinions; iv) help the children to understand the effects of their behaviors on others; and v) plan activities for the children to learn how to contribute to the class and community.

The responses on "community awareness" reveal that through the teachers' practices in the classroom, they are quite aware of the importance of enhancing community awareness in the children. 
One hundred percent (100\%) of the teachers replied that they "always" create an environment of respect for differences in the classroom, whereas $75 \%$ answered "often" for giving the students opportunities to relate to others from different cultures. Also $75 \%$ responded "often" with regards to organizing cultural events through which students learn about different cultures. As to making connections between lessons and students' culture and background, 75\% of the teachers replied "always". Concerning giving opportunities for the students to share their cultural values and traditions, $25 \%$ replied "seldom", $25 \%$ "sometimes", $25 \%$ "often", and 25\% responded "always".

The results of the third section of the questionnaire that concerns "cultural awareness" reveal that through the teachers' practices in the classroom, we can say that they are very aware of the importance of promoting cultural awareness in the children. However, the teachers have to take into consideration to provide students with more opportunities to share their values and traditions.

Seventy-five percent $(75 \%)$ of the teachers responded that "sometimes" they encourage trash separation in the classroom, whereas $25 \%$ replied "always". Fifty percent $(50 \%)$ of the teachers replied "always" for helping children to understand the effects of their behavior on the environment, whereas $75 \%$ of the teachers responded "often" for helping children to understand the source of the resources they use. Also, 75\% answered "always' for helping children to acquire a strong feeling of curiosity and concern for the environment. One hundred percent (100\%) of the teachers indicated that they "always" create activities for the children to learn how to contribute to the wellbeing of the earth.

The results of the fourth section of the questionnaire that concerns "environmental awareness" reveal that through the teachers' practices in the classroom, they are aware of the importance of fostering environmental awareness in the children. However, the teachers may have to encourage children to do more trash separation in the classroom and help them to understand that their behavior can have negative effects on the environment.

The results of the interview and the responses to the questionnaire indicate that through the principal's direction and the teachers' practices in the classroom, the School demonstrates high level of awareness about the importance of enhancing the four aspects or pillars of Peace Education which are deeply rooted in the Montessori Philosophy: self-awareness, community-awareness, cultural-awareness and environmental-awareness in the children who attend the School.

\section{Discussion}

Political, social, economic, and environmental problems that we observe today in Lebanon are mainly rooted in long-term conflicts and disagreements between the diverse sects and different political parties that coexist in the country. A picture of Lebanon today, in 2020, clearly tells that after 15 years of civil war (1975-1990) and despite the fact that the government put a plan for the country to recover, the result is a failure in terms of peace.

Peace at all levels of the Lebanese society is the key element that could dramatically contribute to the development of the nation. If there is no peace, the country will not develop and the political, social, economic, and environmental problems will not be solved. Moreover, every individual in the 
society will be affected if Lebanese people do not live in peace with each other. Then the question is, what would be the most effective channel or tool to incorporate the concept and practice of peace in the minds of the Lebanese population? The researchers believe that it is through education at an early age that substantial progress in this sense can be achieved.

In 1997 after the civil war, the government of Lebanon developed a new curriculum in the Education Program, hoping that the new generation will help in rebuilding the nation. However, after twenty-three years of its implementation, the same problems are still deeply present in the country. In consequence, there is a need for a big change in the individuals that lead the society. This must start from schools by building a new educational program that includes Peace Education as a tool for transformation. Peace Education can help young people to know themselves and understand that everyone is an important part of the community and the country as a whole. There is a need to invest in the youth because they are the future.

Finally, this study takes lessons obtained from the Montessori School and proposes its inclusion in the overall Lebanese Curriculum. The results of the study, based on the interview and the questionnaire that were carried out, demonstrate the following:

1- The five learning areas of the Montessori approach of education and the eight principles that the Lebanese Montessori School has adopted in its curricula contribute to build up the children's character and the development of self-awareness, community-awareness, cultural-awareness, and environmentalawareness which promote Peace through Education. At an early age, children are enlightened by the teachers on global concepts through storytelling, fostering curiosity and promoting exploration. Furthermore, teachers help the children to become aware of the interconnectedness that exists between all of them and the things in their environment. In this way, they instill in them the seeds of love and respect for others and all the living and non-living things in their environment. Teachers help the students to understand that everything has a role in life and each person needs to think of their own roles and how they can contribute positively to the wellbeing of their community and the planet.

2- The school emphasizes fostering conflict resolution and good communication skills which are key skills to apply and promote Peace. Children are taught lessons of grace and courtesy that provide them with ways to behave and respect others. Moreover, through these lessons, teachers offer the children relevant examples of the words to be used in expressing their feelings and how to negotiate in order to solve a conflict. At later stages, teachers use role-play exercises with the children, aiming to practice conflict resolution scenarios. In these practices, the teacher's role is to guide the children in recognizing and expressing their feelings, and then to communicate with the peer that they have a conflict with, in order to talk about those feelings. The likely outcome is a peaceful solution of their differences.

3- The questionnaire results reveal that through their practices in the classroom, the teachers of the Montessori School are aware of the importance of fostering self-awareness. Thus, the teachers encourage children to express their feelings and to be proud of their efforts. Simultaneously, the teachers help them to recognize their inner selves, to be independent through taking care of themselves and giving them time to reflect on their work and improve it by self-correcting. In this way, the school 
prepares the children to strengthen their abilities to monitor their thoughts and emotions and the effect they have on others. Knowing one's self better help to reach an inner peace and that reflects on the relations with others in the community. Self-awareness seeks the knowledge of ourselves in order to enhance the relationship with others and with the environment. We can reach peace in the world when we become aware that it starts within us.

As for community-awareness, the teachers are highly aware in promoting different areas that lead to a better united community. They guide the children in reducing negative competition and increasing respect for others' opinions which lead to build a harmonious relationship among the peers. Moreover, the teachers help the kids to understand that others have needs and this makes them aware that they need to contribute to the community. The key concept in this point is that the school works on creating the concept of community wellbeing is above individual wellbeing in the minds of the children.

Regarding cultural awareness the teachers create different activities to promote cultural awareness in children by introducing them to new cultures and, in this way, creating in them respect for others of different backgrounds. Promoting cultural activities, especially in countries like Lebanon that have been affected by conflicts rooted in internal cultural differences, can help communities to reconnect with their identities which is the beginning to heal from the scars of war. Moreover, cultural activities carried out by the school can help fostering appreciation of the Lebanese cultural diversity and mutual understanding among each other. Developing students' cultural awareness starts by encouraging them to realize their own culture and its relation to others' cultures.

Concerning environmental awareness, the teachers promote curiosity and concern for the environment, so they are planting the seeds of care which will lead the children to think of how they can contribute to the wellbeing of earth. All the teachers' efforts focus on creating a peaceful environment that promotes the development of peaceful individuals. Exposing children to nature at an early age can help them to understand the world and their part in it and this enhances environmental peace- making. The natural resources of the country are there for the benefit of all Lebanese people and, therefore, it is important that each individual takes proper care of those resources. That contributes to peace, too.

4- Comparing the results of this research to previous studies discussed in the literature review, the Program of the Montessori School in Lebanon embraces the concept of Peace Education and the need of its implementation in Lebanon. Moreover, it is also clear that the practices of the teachers are aligned with Maria Montessori's Philosophy aimed to create a more peaceful world.

5- Several lessons can be learned from the Montessori approach of Peace Education that Lebanese Montessori School is applying in its program. In her research about Human Rights and Peace Education in Lebanese textbooks, Maha Shuayb (2015) found that the main focus in the current curriculum is on the theoretical knowledge while the development of skills is totally missing. Moreover, Shuayb concludes that the teaching methods followed in the class pedagogy is descriptive, lacks critical thinking, and steps for its implementation are almost absent. Considering that study as a reference, this research finds that the Lebanese Montessori School fills the gaps. It uses a constructive method where the children are totally involved in their learning and the teachers create a large series of activities for 
children to implement and practice the skills needed to develop mentally, physically, and spiritually. The current Lebanese curriculum teaches about peace only through the textbooks, and this cannot result in peace among people if it is not discovered and practiced by the children in their own learning experiences. Thus, teachers have to avoid lecturing and create an environment that promotes the learning and development of peace within the individuals.

\section{Recommendations}

A deeper research will be required to measure the students' awareness with regards to the four pillars of the Montessori Peace Education concept: self-awareness, community-awareness, culturalawareness, and environmental-awareness. A future research on this issue could be done by questionnaires to both the students and the parents in order to measure the implementation of the Peace Education concepts in the classroom, at home, and in the community. Then results may be used to provide information to the Ministry of Education about the effects of the Peace Education Program on the students and the community.

Another highly recommended future study should be measuring the level of awareness of the teachers in the traditional Lebanese Schools with regards to the four pillars previously referred: selfawareness, community-awareness, cultural-awareness, and environmental-awareness, and comparing the results to the results of this study about Peace Education Program in a Lebanese Montessori School.

\subsection{Implications}

This study will contribute to the benefit of Lebanon considering that Peace Education plays an important role in building and improving appropriate interrelations within society. It can be used as a model for schools and educators to increase awareness in children on the four pillars of Montessori's Peace Education Philosophy, as previously mentioned: self-awareness, community-awareness, culturalawareness, and environmental-awareness. These four aspects are the pillars in building the man/woman of the future, as indicated in previous studies included in the literature review. Peace Education can solve critical problems in schools and in the community; and it is a need for building a better country.

\subsection{Limitations}

A major limitation during the research was the restrictions imposed by the Government in the context of the COVID-19 pandemic. It caused schools closures and hindered the researchers to make direct observations in the classroom that would have helped in collecting additional data about the means utilized by teachers in dealing with children to promote Peace Education. Another limitation was the small sample size of the teachers due to the school staff structure.

\section{Conclusion}

The study responds positively to the three research questions. Firstly, the Lebanese Montessori School promotes Peace Education and the four aspects or pillars of the Montessori philosophy of Peace Education are embedded in the School's Program. Secondly, the teachers in the Lebanese Montessori School are aware of those four levels of awareness and apply them in the lessons and practices of the 
children who attend this educational center. Finally, relevant lessons can be learned from the Montessori approach of Peace Education and can be incorporated in the Lebanese Curriculum.

Peace Education is an essential element that should be improved and developed in the Lebanese national curriculum. Lebanon is in an urgent need to build a better society where all the Lebanese people live in a harmonious environment and this can be done by investing in young children. This research highlighted the Montessori Peace Education program and the teachers' level of awareness in implementing it through promoting in children the pillars of the Montessori Philosophy of Peace Education. These pillars help the children to avoid being self-centered and, to develop love, care for others in their community, in their country, in the entire world; and to understand the interrelationship among all people.

Peace Education is needed to provide members of the community with knowledge and practical skills to avoid violence among them. It can be used as a tool to plant the seeds of peace in the minds and hearts of the young children by reducing violence and promoting new behaviors in our kids. That is why Peace Education is very important not only for Lebanon but also for the whole world so human beings live together in harmony.

Peace education has an immense impact on the students in their classroom and in the entire school. For example, bullying is a form of violence and aggressive behavior that is shown at early ages and it has become a big issue in the Lebanese schools. In a survey conducted by Save the Children in 2018 concluded that half of the kids in Lebanon has been victims of bullying. In that regard, Peace Education can help to reduce bulling and other aggressive behaviors. It can be used as a tool by the educators to teach students how to interact, respect their peers and their teacher; it provides the students with skills to use in group work and in conversation with those around them. Thus, Peace Education can be used to solve several critical problems in the schools.

Moreover, Peace Education emphasizes on showing respect to all kinds of life, which means we are responsible of respecting and protecting the environment that is around us. The natural world is under threat; therefore, Peace Education is important to promote love in our kids for the nature, animals, plants and other elements in the environment. Through Peace Education kids will understand that humans are part of the nature and we, all elements in the environment, are all interconnected.

\section{References}

[1] Aden, S. (2017). Exploring the role of peace education in schools in post-conflict Somalia.[Doctoral dissertation]. Southern New Hamshire University.

[2] Alfonso, S. M. (2014). Peace education in early childhood education. Journal of Peace Education and Social Justice, 8(2), 167-188.

[3] Baja, M. (Ed.). (2008). Encyclopedia of peace education. Information Age Publishing.

[4] Bakken, L., Brown, N., \& Downing, B. (2017). Early childhood education: Long-Term Benefits. Journal of Research in Childhood Education, 31(2), 255-569. 
[5] Baligadoo, P. (2014). Peace profile: Maria Montessori-peace through education. Peace Review: A Journal of Social Justice, 26(3), 427-433. https://doi.org/10.1080/10402659.2014.938003

[6] Cabedo-Mas, A. (2015). Challenges and perspectives of peace education in schools: The role of music. Australian Journal of Music Education, (1), 76-86.

[7] Carter, S. \& John J. Wheeler, J. (2019). The social validity manual: Subjective evaluation of interventions $\left[2^{\text {nd }}\right.$ edition]. Academic Press.

[8] Coertjens, L., Pauw, J., De Maeyer, S., \& Petegem, P. (2010). Do Schools Make A Difference in Their Students' Environmental Attitudes and Awareness? Evidence From Pisa 2006. International Journal of Science and Mathematics Education, 8, 497-522. https://doi.org/10.1007/s10763-010-9200-0

[9] Chehimi, G. (2012). Peace education: An expoloratory assessment of Lebanese University students' attitudes using focus group approach. International J. Soc. Sci. \& Education, 2(4), 782-797.

[10] Chturvedi A., Kumari R., \& Singh, S. (2014). Environmental awareness through education. Shaikshik Parisamvad International Journal of Education, 4(2), 9-13.

[11] Demante D., Tambovceva, T. \& Atstaja, D. (2016). Raising environmental awareness through education. International Journal of Continuing Engineering Education and Life-Long Learning, 26(3), 259-272. doi:10.1504/IJCEELL.2016.078446

[12] Flavian, H. (2016). Towards teaching and beyound: Strengthening education by understanding students' self-awareness development. Power and Education, 8(1), 88-100. https://doi.org/10.1177/1757743815624118

[13] Hadzigeorgiou, Y, \& Skoumios, M. (2013). The development of environmental awareness through school science: Problems and possibilities. International Journal of Environmental \& Science Education, 8, 405-426. doi:10.12973/ijese.2013.212a

[14] Harris, I. \& Morrison, M. (2013). Peace Education. McFarland.

[15] Howlette, C. F. (2008). John Dewey and peace pducation. Teachers College Columbia.

[16] Huynh, S. (2018). Social awareness and responsible decision making of students in grade 4 and 5 in Vietnam. Journal of Education and Human Development, 7(4), 7-15. doi:10.15640/jehd.v7n4a2

[17] Isoraite, M. (2019). The importance of education in peace marketing. Integrated Journal of Business and Economics, 3(1),43-51.

[18] Jabbour, K. (2013). Peace education in the Lebanese curriculum. Anadolu Journal of Education Sciences International, 3(2), 52-57.

[19] Jin-Feng, K. (2007, December). www.davidpublisher.org 
[20] John Paul II. (1979). Message of his holliness Pope John Paul II for the celebration of the day of peace. Libreria Editrice.

[21] Laal, Marjan, Laal, Mozhgan, \& Kermanshahi, Z. (2012). 21st century learning: Learning incollaboration. Procedia-Social and Behavioral Science, 47, 1696-1701. doi:10.1016/j.sbspro.2012.06.885

[22] Lasi, S., Jiwan, J., Batool, Z., Dhanani, S., \& Shrestha, K. (2017). Peace building in the minds of early childhood education teachers voices from Pakistan. Journal of Early Childhood Care and Education, 1, 43-58.

[23] Lebanese Montessori School. (2020). www.lms-lb.com

[24] Lillard, A. (2005). Montessori: The science behind the genius. Oxford University Press.

[25] Littledyke, M. (2008). Science education for environmental awareness: Approaches to integrating cognitive and affective domains. Environmental Education Research, 14(1), 1-17. https://doi.org/10.1080/13504620701843301

[26] Livonen M., Sonnenwald, D., Parma, M., \& Poole-Kober, E. (1998, August 16-21). Analyzing and understanding cultural differences: Experiences from education in library and information studies [Paper presentation]. 64th IFLA General Conference, Amsterdam, Netherlands.

[27] Mahan, K. (2018). The Impact of grace and courtesy instruction and modeling on the normalization of a Montessori primary classroom [Master's thesis, Saint Catherine University]. Sophia. https://sophia.stkate.edu/maed/282

[28] McClellan, D., \& Kinesy, S. (1999). Children's social behavior in relation to participation in mixedage or same-age classrooms. Early Childhood Research \& Practice, 1(1). https://www.ecrp.illinois.edu/v1n1/mcclellan.html

[29] McFarland, S. (2012). Nurturing the peace flower: A model for the science of peace. Shining Mountains Press. http://www.shiningmountainspress.com/teachers-caregivers/nurturing-thepeace-flower-a-model-for-the-science-of-peace-2/

[30] Navarro-Castro, L., \& Nario-Galace, J. (2008). Peace education: A pathway to a culture of peace. Philippines: Center for Peace Education, Miriam College.

[31] Montessori, M. (1949). The Absorbent Mind. The Montessori-Pierson Publishing company.

[32] Montessori, M. (1951). Education and peace. Montessori-Pierson Publishing Company.

[33] Montessori, M. (1967). The Discovery of The Chid. New York: The Random House Publishing Group.

[34] Oliva, P. (2004). Developing the Curriculum. Pearson. 
[35] Russell, M. (2014). Connecting children to nature in a Montessori primary environmnt [Master's thesis, University of Wisconsin - River Falls]. UWRF Graduate Research Papers.

[36] Silvia, P., \& Duval, T. S. (2001). Objective self-awareness theory: Recent progress and enduring problems. Personality and Social Psychology Review, 5(3), 230-241. doi: 10.1207/S15327957PSPR0503_4

[37] Schaefer, P. (2015). Grace and courtesy and beyond. NAMTA, 40(1), 33- 49.

[38] Shemshadsara, Z. (2012). Developing Cultural Awareness in Foreign Language Teaching. English Language Teaching, 5(3), 95-99. doi:10.5539/elt.v5n3p95

[39] Sheykhjan, T. (2014, 12-13 December). Global peace education in 21st century [Paper presentation]. National Conference on Trends and Innovations in Gandhian Thought, India.

[40] Shuayb, M. (2015). Human rights and peace education in the Lebanese textbooks. Research in $\begin{array}{llll}\text { Comparative } \quad \& \quad \text { International } \quad \text { Education, } & \text { 10(1), }\end{array}$ https://doi.org/10.1177\%2F1745499914567823

[41] Snauwaert, D. (2012). Batty Reardon's conception of "peace" and its implications for a philisophy of peace education. Peace Studies Journal, 5(3), 45-52.

[42] Somerton-Burkhardt, H. (2015). Creating a normalized Montessori classroom [Master's thesis, St. Catherine University]. St. Catherine University Repisotry. https://sophia.stkate.edu/maed/119.

[43] UN Environmnet. (2020). www.unenvironment.org

[44] UNESCO. (2008). UNESCO's work on education for peace and non-violence: Building peace through education. ED.2008/WS/38. UNESCO Digital Library. https://unesdoc.unesco.org/ark:/48223/pf0000160787

[45] UNESCO. (2013). The role of culture in peace and reconciliation. www.unesco.org

[46] UNICEF. (2014). Peace building through early childhood development. UNICEF Education Section. 


\section{Appendix I}

\section{Interview Questions}

1- What is in general the inclusion of peace education in the curricula at your school?

2- Tell me how your Montessori school promotes "peace" through self-awareness activities.

3- Tell me how your Montessori school promotes "peace" through community activities.

4- Tell me how your Montessori school promotes "peace" through cultural activities.

5- Tell me how your Montessori school promotes "peace" through environmental activities.

6- Do you find any challenges to implement the Montessori concepts in the Lebanese culture and environment?

7- What is your opinion about teaching Peace education in early childhood? 


\section{Appendix II}

\section{Questionnaire}

Directions: Please indicate how frequent you apply these practices.

\begin{tabular}{|c|c|c|c|c|c|}
\hline A. Self-Awareness & Never & Seldom & Sometimes & Often & Always \\
\hline $\begin{array}{l}\text { 1. I encourage children to express their feelings } \\
\text { and emotions. }\end{array}$ & 1 & 2 & 3 & 4 & 5 \\
\hline 2. I help children to be proud of their efforts. & 1 & 2 & 3 & 4 & 5 \\
\hline $\begin{array}{l}\text { 3. I give the children time to self-correct their } \\
\text { work. }\end{array}$ & 1 & 2 & 3 & 4 & 5 \\
\hline $\begin{array}{l}\text { 4. I create activities through which children learn } \\
\text { to take care of themselves. }\end{array}$ & 1 & 2 & 3 & 4 & 5 \\
\hline $\begin{array}{l}\text { 5. I create opportunities for children to be } \\
\text { independent. }\end{array}$ & 1 & 2 & 3 & 4 & 5 \\
\hline \multicolumn{6}{|l|}{ B. Community Awareness } \\
\hline 1. I help children to be aware of others' needs. & 1 & 2 & 3 & 4 & 5 \\
\hline $\begin{array}{l}\text { 2. I encourage cooperative learning activities and } \\
\text { discourage negative competition among } \\
\text { learners. }\end{array}$ & 1 & 2 & 3 & 4 & 5 \\
\hline $\begin{array}{l}\text { 3. I encourage children to build a harmonious } \\
\text { relationship with their peers. }\end{array}$ & 1 & 2 & 3 & 4 & 5 \\
\hline $\begin{array}{l}\text { 4. I encourage children to value and respect other } \\
\text { opinions and ideas. }\end{array}$ & 1 & 2 & 3 & 4 & 5 \\
\hline $\begin{array}{l}\text { 5. I help children to understand the effects of their } \\
\text { behavior on others. }\end{array}$ & 1 & 2 & 3 & 4 & 5 \\
\hline $\begin{array}{l}\text { 6. I plan for activities for the children to learn } \\
\text { how they can contribute to the class or the } \\
\text { community. }\end{array}$ & 1 & 2 & 3 & 4 & 5 \\
\hline \multicolumn{6}{|l|}{ C. Cultural Awareness } \\
\hline $\begin{array}{l}\text { 1. I create in the classroom an environment of } \\
\text { respect of differences. }\end{array}$ & 1 & 2 & 3 & 4 & 5 \\
\hline $\begin{array}{l}\text { 2. I provide an opportunity for the students to } \\
\text { relate to others from different cultures. }\end{array}$ & 1 & 2 & 3 & 4 & 5 \\
\hline $\begin{array}{l}\text { 3. I organize for cultural events through which } \\
\text { students learn about different cultures. }\end{array}$ & 1 & 2 & 3 & 4 & 5 \\
\hline $\begin{array}{l}\text { 4. I provide opportunities in the classroom for } \\
\text { students to share their cultural values and } \\
\text { traditions. }\end{array}$ & 1 & 2 & 3 & 4 & 5 \\
\hline $\begin{array}{l}\text { 5. I make connections between lessons and } \\
\text { students' culture and backgrounds. }\end{array}$ & 1 & 2 & 3 & 4 & 5 \\
\hline \multicolumn{6}{|l|}{ D. Environmental Awareness } \\
\hline 1. I encourage trash separation in the classroom. & 1 & 2 & 3 & 4 & 5 \\
\hline 2. I help children to understand the effects of their & 1 & 2 & 3 & 4 & 5 \\
\hline
\end{tabular}




\begin{tabular}{|c|c|c|c|c|c|}
\hline behavior on the environment. & & & & & \\
\hline $\begin{array}{l}\text { 3. I help children to understand that all the } \\
\text { resources we use come from the natural world. }\end{array}$ & 1 & 2 & 3 & 4 & 5 \\
\hline $\begin{array}{l}\text { 4. I help children to acquire strong feeling of } \\
\text { curiosity and concern for the environment. }\end{array}$ & 1 & 2 & 3 & 4 & 5 \\
\hline $\begin{array}{l}\text { 5. I create activities for the children to learn how } \\
\text { they can contribute to the wellbeing of the } \\
\text { earth. }\end{array}$ & 1 & 2 & 3 & 4 & 5 \\
\hline
\end{tabular}

